\title{
The COVID-19 with Gastrointestinal Symptoms: A Case Report
}

\author{
Eka Surya Nugraha*,**, Davin Takaryanto*, Susantina Prodjosoewojo*,***, \\ Nenny Agustanti*** \\ *Department of Internal Medicine, Faculty of Medicine, Universitas Padjadjaran/ \\ Dr. Hasan Sadikin General Hospital, Bandung \\ ${ }^{* *}$ Division of Gastroenterology and Hepatology, Department of Internal Medicine \\ Faculty of Medicine, Universitas Padjadjaran /Dr. Hasan Sadikin General Hospital, Bandung \\ ${ }^{* * *}$ Division of Infectious Diseases and Tropical Medicine, Department of Internal Medicine \\ Faculty of Medicine Universitas Padjadjaran/Dr. Hasan Sadikin General Hospital, Bandung
}

\section{Corresponding author:}

Eka Surya Nugraha. Division of Gastroenterology and Hepatology, Department of Internal Medicine, Dr. Hasan Sadikin General Hospital, Universitas Padjadjaran. Jl. Pasteur 38 Bandung Indonesia. Phone: +62-22-2034953; Facsimile: +62-22-2040151. E-mail: eka.surya@unpad.ac.id

\section{ABSTRACT}

The COVID-19 mostly manifested as fever and pulmonary symptoms, but recent evidence demonstrated the frequent gastrointestinal symptoms in particular moderate to severe disease. Here, we present a case of a 51-years old man with confirmed COVID-19 diagnosis who was admitted with profuse acute diarrhea and nausea. He previously had a mild fever, cough, and shortness of breath. Administration of oseltamivir, levofloxacin, and chloroquine sulfate exaggerated vomiting, nausea, and increased serum level transaminase. After withdrawal, the gastrointestinal symptoms were relieved gradually. Adequate supportive treatment and fluid therapy ceased diarrhea and led to the negative result of the nasal swab reverse transcription polymerase chain reaction (RTPCR) COVID-19 after seven days.

Keywords: COVID-19, gastrointestinal symptoms, supportive treatment

\begin{abstract}
ABSTRAK
COVID-19 pada umumnya bermanifestasi dengan demam atau gejala sistem pernafasan, tetapi bukti terbaru menunjukkan bahwa gejala gastrointestinal sering pula terjadi terutama pada kasus sedang dan berat. Pada laporan kasus ini, kami menampilkan kasus seorang pria berusia 51 tahun yang tegak diagnosis COVID-19, dengan gejala mual hebat dan diare akut. Pasien sebelumnya mengeluhkan demam, batuk, dan sesak ringan. Setelah pemberian oseltamivir, levofloxacin, dan kloroquin sulfat, gejala gastrointestinal semakin memberat, disertai dengan peningkatan serum transaminase. Gejala berangsur-angsur membaik setelah penghentian obat. Terapi suportif dan pemberian cairan yang adekuat menunjukkan perbaikan kondisi pada pasien, dengan hasil reverse transcription polymerase chain reaction (RT-PCR) dari apus hidung negatif untuk COVID-19 setelah tujuh hari perawatan.
\end{abstract}

Kata kunci: COVID-19, gejala gastrointestinal, perawatan suportif 


\section{INTRODUCTION}

Severe acute respiratory coronavirus 2 (SARS-CoV-2) that caused coronavirus disease 2019 (COVID-19) initially reported in Wuhan, Hubei Province, China, in December 2019. The disease became a global pandemic, until May 2020, approximately 4 million infected with more than 300,000 deaths globally. ${ }^{1,2}$

Fever, cough, and shortness of breathing accounted for 41 to $91 \%$ of COVID-19 symptoms, the headache, diarrhea, nausea, and vomiting also presented in a small proportion. ${ }^{3}$ Although the gastrointestinal system symptoms less reported as COVID-19 manifestation compared to the pulmonary systems, recent studies are reporting an increase of gastrointestinal and liver injury manifestations, particularly in moderate to severe disease. ${ }^{4}$

Current findings revealed that angiotensinconverting enzyme 2 (ACE2) receptor, which responsible as the primary binding site for SARSCoV-2, expressed abundantly in the gastrointestinal tract and liver cell as well. ${ }^{5}$

Gastrointestinal symptoms and liver injury reported in 15 and $19 \%$ of COVID-19 patients from a metanalysis, respectively. The gastrointestinal symptoms presented solely in about $10 \%$ of COVID-19 without any attributable symptoms of other organ systems. ${ }^{4}$ Here we reported a confirmed COVID-19 case with predominant diarrhea and nausea without significant respiratory symptoms who were improving after appropriate supportive therapies.

\section{CASE ILLUSTRATION}

A 51-year-old man with the mentally disabled was brought by his caregiver to our hospital due to severe watery diarrhea. He experienced eight times of acute watery diarrhea followed with nausea without vomiting one day before admitting. Neither mucous, blood nor foul smell were found from the feces. Previously, the patient has a history of dry cough and shortness of breath accompanied by mild fever from 10 days before admission, then settled after three days hospitalized in a private hospital. He was diagnosed as pulmonary tuberculosis based on chest computed tomography (CT) scan findings. Therefore, he started the antituberculosis drugs. According to the anamnesis from his caregiver, he had a contact with a confirm COVID-19 who died two weeks ago. We conducted a rapid test examination for COVID-19 to them; the result was positive for the patient, but contrary to the caregiver. The patient was transferred to the isolation room for COVID-19 and undergo the RT-PCR swab test. Due to our laboratory limitations, the result will be available for the next 3 or 4 days.

The physical examination on the first day of admission showed the patient was well conscious. His blood pressure was $140 / 95 \mathrm{mmHg}$, pulse rate 116 beats per minute, the respiration 20 rate per minute, and the body temperature was 37.0 degrees Celsius. The abdominal examination revealed a mild epigastric pain with the visual analog score (VAS) 3 of 10. The oxygen saturation from room air was $97 \%$. The chest X-ray showed an infiltrate in both lungs, suggesting bilateral pneumonia. The blood examination yielded a slight increase of platelets count, the hemoglobin, leukocyte count was normal, but a low total lymphocyte count (see Table 1). Creatinine and electrolyte were also normal (see Table 1). Routine stool examination yielded a typical result.

\begin{tabular}{lcl}
\multicolumn{3}{l}{ Table 1. Baseline laboratory results at admission (day-1) } \\
\hline Measure & Result & Reference \\
\hline Hemoglobin (gr/dL) & 13.2 & $12.3-15.3$ \\
White blood cell count $\left(10^{3} / \mathrm{uL}\right)$ & 7.2 & $4.4-11.3$ \\
Lymphocyte count $(/ \mathrm{uL})$ & 649 & $>1,500$ \\
Platelet count $\left(10^{3} / \mathrm{uL}\right)$ & 426 & $150-450$ \\
C-reactive protein $(\mathrm{mg} / \mathrm{L})$ & 3.31 & $<0.3$ \\
Aspartate transaminase $(\mathrm{U} / \mathrm{L})$ & 90 & $15-37$ \\
Alanine transaminase $(\mathrm{U} / \mathrm{L})$ & 65 & $14-59$ \\
Ureum (mg/dL) & 39 & $15-39$ \\
Creatinine (mg/dL) & 1.1 & $0.5-1.1$ \\
Sodium (meq/L) & 137 & $135-145$ \\
Potassium (meq/L) & 3.3 & $3.5-5.1$ \\
Calcium (mg/dl) & 5.0 & $4.5-5.6$ \\
Magnesium (mg/dl) & 1.7 & $1.8-2.4$ \\
Random Blood Glucose (mg/dL) & 83 & $<140$ \\
Procalcitonin & 0.12 & $0.17-0.32$ \\
HbsAg & $\mathrm{NR}$ & $\mathrm{NR}$ \\
Anti-HCV & $\mathrm{NR}$ & $\mathrm{NR}$ \\
\hline
\end{tabular}

$\mathrm{NR}=$ Non-reactive

During hospitalization in our hospital, diarrhea persisted, but the frequency decreased to 4 times a day. Nausea and vomiting occasionally occurred, but no fever was documented. The patient had stopped the anti-tuberculosis drug since he acquired diarrhea. Upon the third day of treatments, RT-PCR nasal swab confirmed positive for COVID-19.

According to our hospital procedure for the suspected COVID-19 before the real-time polymerase chain reaction (RT-PCR) ready, the patient was treated with oseltamivir $150 \mathrm{mg}$ BID, levofloxacin 750mg QD, and chloroquine sulfate $500 \mathrm{mg}$ BID. However, after three days, we terminated these treatments due to excessive nausea, vomiting, and an increase of AST (90 to 194 $\mathrm{U} / \mathrm{L}$ ) and ALT level (65 U/L to $270 \mathrm{U} / \mathrm{L}$ ) consecutively. Although the RT-PCR result yielded positive for COVID-19 upon the third day of treatments, we 
decided to postpone the treatment until gastrointestinal symptoms settled. The patient was administered a prokinetic agent and maintenance intravenous fluid as supportive treatments. Diarrhea occurred 3 to 4 times a day then stopped on the seventh day from the admission. Repeated RT-PCR swab test at day-7 of admission resulted in negative for COVID-19. After day-7, the feces consistency returned to normal; subsequently, the serial chest X-rays showed a significant reduction of lung infiltrates. Finally, third nasal swab PCR at day-14 yielded a negative result for COVID-19. The patient discharged from the hospital after 17 days of hospitalization. The latest AST and ALT levels were 95 and $101 \mathrm{U} / \mathrm{L}$ consecutively (see Figure 1).

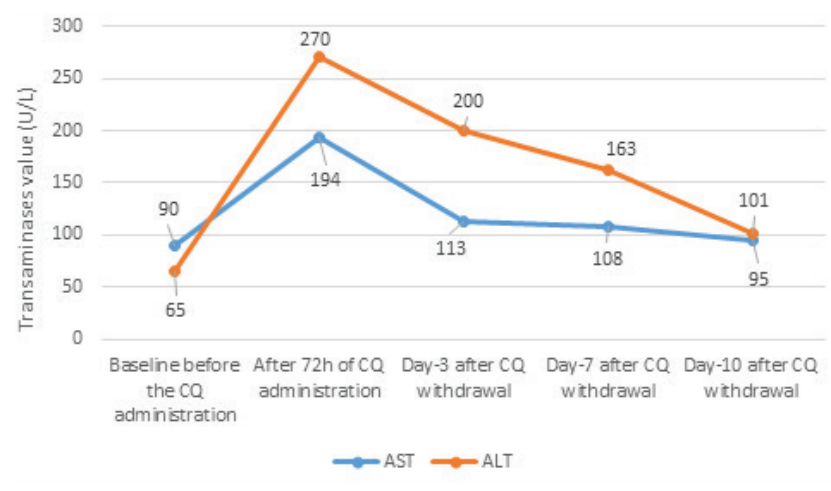

Figure 1. The transaminases kinetic of COVID-19 patient from the baseline, after administration, and follow-up after withdrawal. $C Q=$ Chloroquine $; A S T=$ Aspartate aminotransferase $; A L T=$ Alanine aminotransferase

\section{DISCUSSION}

Gastrointestinal symptoms were accounted for 15 to $17.6 \%$ of COVID-19 patients. ${ }^{4,6}$ Most gastrointestinal symptoms of COVID-19 were nausea and vomiting, with or without diarrhea. ${ }^{6} \mathrm{~A}$ recent metanalysis mentioned the gastrointestinal symptoms related to the severity of COVID-19 manifestation. The proportion of patients with severe and critical COVID-19 was markedly increased in patient with gastrointestinal symptoms compared to those without gastrointestinal symptoms. ${ }^{4}$

The gastrointestinal symptoms in COVID-19 may present before or after symptoms of the other organ system. Wang et al mentioned that $10 \%$ of COVID-19 patients showed nausea, vomiting, and diarrhea before the development of fever or shortness of breath. ${ }^{1}$ Other studies by Pan et al which collected the clinical characteristic across multiple centers in Hubei, China, the epicenter of COVID-19. They showed that respiratory and digestive symptoms accounted for $47.5 \%$, while respiratory symptoms only accounted for $41.2 \%$, and digestive symptoms only yielded about $3 \%{ }^{7}$

In our case, according to the deep anamnesis from the caregiver, the mild pulmonary symptoms and fever preceded the gastrointestinal symptoms. After the administration of the symptomatic drug for cough and fever, the symptoms relieved on three days but developed acute diarrhea thereafter and persisted for the next seven days. Holshue et al reported the very first COVID-19 case in the United States; fever and cough occurred early, followed by nausea and vomiting on day-3 of illness. Diarrhea and abdominal discomfort then arose at day- 6 of illness, persisted in the next two days. ${ }^{8}$ The digestive symptoms were common in COVID-19 patients. ${ }^{7}$

The exact pathomechanism of involving SARS$\mathrm{CoV} 2$ in the gastrointestinal tract has not been fully understood. However, the SARS-CoV2 may directly or indirectly damage the digestive system through the inflammatory responses. The chain reaction of inflammatory factors and viremia may injure the digestive system. ${ }^{7,9}$ Previous evidence showed that viral nucleic acid was detected in stool samples in up to $53.4 \%$ of COVID patients. The viruses directly damage the intestinal mucosa and cause digestive symptoms, but further research is needed to confirm this possibility. ${ }^{10,11}$

The ACE2 receptor that the primary receptor of SARS-CoV-2 to binding with cells was highly expressed in the gastrointestinal tract and liver cells as well. ${ }^{5,6}$ The majority of ACE2 receptors are expressed in the small intestine, in the proximal and distal enterocytes. SARS-CoV-2 disrupted the ACE2 receptor and resulted in diarrhea manifestation. ${ }^{6}$ The role of SARS-CoV-2 successfully invaded enterocytes of the digestive tracts, depends not only on the presence of cell receptor ACE2 but also the cellular serine protease and transmembrane protease serine 2 (TMPRSS2), which cleaves the S-protein of human coronaviruses on the cell membrane, both of which are critical for the fusion of viral and the cellular membranes. ${ }^{12}$ Moreover, the virus itself may cause disorders of the intestinal flora, which could result in digestive symptoms. ${ }^{7}$

According to recent literature evidence, the SARS-CoV-2, in our case, may binding to both ACE2 receptors in the respiratory and gastrointestinal tract. Therefore, we tried to acquire specimens from the rectal swab RT-PCR. Unfortunately, we withdrew it due to the limitation of our laboratory facilities in processing RT-PCR COVID-19 from fecal specimens. In contrast to the previous study by Mao et al, in this case, the gastrointestinal symptoms not followed by a more severe condition of COVID-19. A similar case report by Azwar et al in Indonesia, described that the gastrointestinal symptoms alongside the pulmonary did not deteriorate the condition of COVID-19., ${ }^{4,13}$ 
From our observation, on day three, after admission and administration of the oseltamivir, quinolones, and chloroquine sulfate, the gastrointestinal symptoms were aggravating. Nausea and vomiting became frequent. The AST and ALT levels also increased three times above reasonable baseline values. We tried to investigate these AST and ALT increments from the literature. The COVID-19 patients with digestive symptoms had laboratory derangements, including prolonged coagulation and higher liver enzymes tests. ${ }^{7}$ Meanwhile, the elevation of AST and ALT levels possibly due to the administration of oseltamivir, quinolones, and chloroquine sulfate but scarcely reported. ${ }^{14-16}$ The summary causes of elevated liver enzymes in COVID-19 are the direct infection of SARS-CoV-2 to the liver cells, drug-induced, or the underlying chronic liver disease including alcohol or non-alcoholic fatty liver disease, chronic hepatitis B or $\mathrm{C}$, and the liver malignancies. ${ }^{17}$

We decided to terminate the oseltamivir, quinolone, and chloroquine sulfate as suspected drugs, which induced aggravating gastrointestinal symptoms and liver injury. Therefore, we optimized supportive fluid replacement and maintenance therapies, symptomaticrelieving drugs, including the proton pump inhibitor (PPI) and prokinetic agents, and diet modifications to the patient. The patient's condition improved significantly after seven days of hospitalized without specific treatments for COVID-19. Upon the nasal swab for the RT-PCR, COVID-19 was negative as well.

According to a recent WHO guideline for the management of COVID-19, we stratified this patient as a mild disease. He had evidence of infiltrate in both suggestive lung pneumonia from chest X-rays; nevertheless, no sign of pneumonia clinically. The gastrointestinal symptoms overt after relieving fever, cough, and shortness of breath, then settled after seven days. The current WHO guideline recommends the management for mild COVID-19 are isolation in a health facility or self-isolation, symptomatic treatment such as acetaminophen for fever or pain, adequate nutrition, and appropriate rehydration. The prophylaxis antibiotic was prohibited. ${ }^{3}$ This case emphasized that supportive treatments were sufficient for mild COVID-19 with gastrointestinal symptoms.

\section{CONCLUSION}

This case report demonstrated a confirmed COVID-19 patient with prominent gastrointestinal symptoms. Appropriate treatments based on the case definition of COVID-19 disease severity are essential to achieve excellent outcomes and avoiding adverse events.

\section{REFERENCES}

1. Guan W, Ni Z, Hu Y, Liang WH, Ou CQ, He JX, et al. Clinical Characteristics of Coronavirus Disease 2019 in China. N Engl J Med 2020;382:1708-20.

2. Cucinotta D, Vanelli M. WHO Declares COVID-19 a Pandemic. Acta Bio-Medica Atenei Parm 2020;91:157-60.

3. World Health Organization. Clinical Management of COVID-19: Interim Guidance, 27 May 2020. World Health Organization; 2020.

4. Mao R, Qiu Y, He JS, Tan JY, Li XH, Liang J, et al. Manifestations and prognosis of gastrointestinal and liver involvement in patients with COVID-19: a systematic review and meta-analysis. Lancet Gastroenterol Hepatol 2020;0:x.

5. Qi F, Qian S, Zhang S, Zhang Z. Single cell RNA sequencing of 13 human tissues identify cell types and receptors of human coronaviruses. Biochem Biophys Res Commun 2020;526:135-40.

6. Cheung KS, Hung IFN, Chan PPY, Lung KC, Tso E, Liu R, et al. Gastrointestinal manifestations of SARS-CoV-2 infection and virus load in fecal samples from the Hong Kong cohort and systematic review and meta-analysis. Gastroenterology 2020;159:81-95

7. Pan L, Mu M, Yang P, Sun Y, Wang R, Yan J, et al. Clinical characteristics of COVID-19 patients with digestive symptoms in Hubei, China: a descriptive, cross-sectional, multicenter study. Am J Gastroenterol 2020;115:766-73.

8. Holshue ML, DeBolt C, Lindquist S, Lofy KH, Wiesman J, Bruce H, et al. First Case of 2019 Novel Coronavirus in the United States. N Engl J Med 2020;382:929-36.

9. Gu J, Han B, Wang J. COVID-19: gastrointestinal manifestations and potential fecal-oral transmission. Gastroenterology 2020;158:1518-9.

10. Tang A, Tong ZD, Wang HL, Dai YX, Li KF, Liu JN, et al. Detection of Novel Coronavirus by RT-PCR in stool specimen from asymptomatic child, China. Emerg Infect Dis 2020;26:1337-9.

11. Xie C, Jiang L, Huang G, Pu H, Gong B, Lin H, et al. Comparison of different samples for 2019 novel coronavirus detection by nucleic acid amplification tests. Int J Infect Dis IJID Off Publ Int Soc Infect Dis 2020;93:264-7.

12. Ng SC, Tilg H. COVID-19 and the gastrointestinal tract: more than meets the eye. Gut 2020;69:973.

13. Azwar MK, Kirana F, Kurniawan A, Handayani S, Setiati S. Gastrointestinal presentation in COVID-19 in Indonesia: A case report. Acta Med Indones 2020;52:63-7.

14. Falcão MB, Cavalcanti LP de G, Filho NMF, Brito CAA de. Case report: hepatotoxicity associated with the use of Hydroxychloroquine in a patient with COVID-19. Am J Trop Med Hyg 2020;102:1214-6.

15. Schloss M, Becak D, Tosto ST, Velayati A. A Case of Levofloxacin-induced hepatotoxicity. Am J Case Rep 2018;19:272-6.

16. Fang S, Qi L, Zhou N, Li C. Case report on alimentary tract hemorrhage and liver injury after therapy with oseltamivir: A case report. Medicine (Baltimore) 2018;97:e12497.

17. Zhang C, Shi L, Wang FS. Liver injury in COVID-19: management and challenges. Lancet Gastroenterol Hepatol 2020;5:428-30. 